STUDIA I PRACE WYDZIAŁU NAUK EKONOMICZNYCH I ZARZĄDZANIA NR 42, T. 2

DOI: $10.18276 /$ sip. $2015.42 / 2-130$

\author{
Karol Mrozik ${ }^{*}$ \\ Uniwersytet Przyrodniczy w Poznaniu
}

\title{
MIEJSCOWE PLANY ZAGOSPODAROWANIA PRZESTRZENNEGO JAKO ELEMENT MONITORINGU ROZWOJU LOKALNEGO
}

\begin{abstract}
STRESZCZENIE
Planowanie zagospodarowania przestrzennego jest jednym z podstawowych narzędzi realizacji rozwoju lokalnego przez samorządy gminne. Z kolei monitoring jest niezbędny dla skutecznego i efektywnego oddziaływania samorządu gminnego na rozwój lokalny. $\mathrm{W}$ artykule oceniono pokrycie planistyczne w gminach wiejskich powiatu poznańskiego. Szczegółową analizę jakościową obowiązujących mpzp uwzględniającą wskaźniki zagospodarowania terenu i kształtowania zabudowy kubaturowej stosowane w planach miejscowych, przeprowadzono dla mpzp dotyczących terenów zabudowy mieszkaniowej jednorodzinnej (ogółem 26) w obrębie geodezyjnym Skórzewo, gmina Dopiewo, powiat poznański.
\end{abstract}

Słowa kluczowe: miejscowy plan zagospodarowania przestrzennego, rozwój lokalny, suburbanizacja, monitoring, gmina wiejska

\section{Wprowadzenie}

Według Jerzego J. Paryska ${ }^{1}$ rozwój lokalny to kompleks przeobrażeń jakościowych dotyczących danego obszaru, a odnoszących się do poziomu życia ludności oraz warunków funkcjonowania podmiotów gospodarczych. Natomiast za jeden

\footnotetext{
*Adres e-mail: kmrozik@up.poznan.pl.

1 J.J. Parysek, Podstawy gospodarki lokalnej, Wydawnictwo Uniwersytetu im. Adama Mickiewicza. Poznań 2001, s. 18-23.
} 
z podstawowych problemów rozwoju lokalnego uznaje działania na rzecz zagwarantowania ładu przestrzennego. Z kolei Ryszard Brol ${ }^{2}$ uznaje rozwój lokalny za systematyczne i zharmonizowane działanie zmierzające do kreowania nowych i poprawy istniejących walorów użytkowych gminy, tworzenia korzystnych warunków dla lokalnej gospodarki oraz zapewnienia ładu przestrzennego i ekologicznego.

Sprawy związane z ładem przestrzennym należą do zadań własnych gminy ${ }^{3}$ i obejmują kształtowanie i prowadzenie polityki przestrzennej na terenie gminy, w tym uchwalanie studium uwarunkowań i kierunków zagospodarowania przestrzennego gminy (zwane dalej: studium) oraz miejscowych planów zagospodarowania przestrzennego (zwane dalej: mpzp lub plany miejscowe) ${ }^{4}$, w których dokonuje się ustalenia przeznaczenia terenu i rozmieszczenia inwestycji celu publicznego oraz określenia sposobów zagospodarowania i warunków zabudowy terenu ${ }^{5}$. Do zadań związanych $\mathrm{z}$ ładem przestrzennym należy także prowadzenie monitoringu zmian zachodzących $\mathrm{w}$ zakresie planowania przestrzennego $\mathrm{w}$ gminie, co realizowane jest poprzez analizy zmian w zagospodarowaniu przestrzennym gminy oraz ocenę postępów w opracowywaniu planów miejscowych. Zadania te wykonuje wójt, burmistrz lub prezydent miasta $\mathrm{w}$ celu oceny aktualności studium i mpzp przynajmniej raz w czasie kadencji rady gminy. Częścią takiej oceny powinien być wieloletni program sporządzania mpzp w nawiązaniu do ustaleń studium ${ }^{6} \mathrm{z}$ uwzględnieniem decyzji o ustaleniu lokalizacji inwestycji celu publicznego (decyzja o ulicp) i decyzji o ustaleniu warunków zabudowy (decyzja o wz) oraz wniosków w sprawie sporządzenia lub zmiany planu miejscowego.

W celu monitoringu zadań dotyczących ładu przestrzennego GUS prowadzi w ramach programu badań statystycznych statystyki publicznej badania na temat „Planowania przestrzennego w gminach”. Źródłem danych są przekazywane w formie elektronicznej formularze PZP-1. Dane statystyczne wójtowie (burmistrzowie, prezydenci miast) przekazują raz do roku (według najnowszego rozporządzenia do

${ }^{2}$ R. Brol, Rozwój lokalny - nowa logika rozwoju gospodarczego, w: Gospodarka lokalna w teorii i praktyce, PN AE we Wrocławiu nr 785, Wrocław 1998, s. 11-15.

${ }^{3}$ Artykuł 7.1.1 ustawy z 8 marca 1990 r. o samorządzie gminnym (DzU z 2013 r., poz. 594 ze zm.).

${ }^{4}$ Artykuł 3.1 ustawy z 27 marca 2003 r. o planowaniu i zagospodarowaniu przestrzennym (DzU z 2015 r., poz. 199 ze zm.).

\footnotetext{
5 Tamże, art. 4.1.

${ }_{6}^{6}$ Tamże, art. 32, 57 i 67.
} 


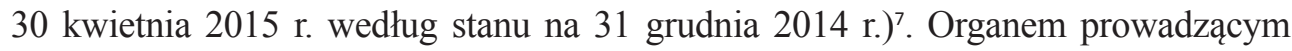
badania jest obecnie Minister Infrastruktury i Rozwoju. Analizy i interpretacji uzyskanych danych statystycznych dokonuje na zlecenie Ministra Infrastruktury i Rozwoju zespół pracowników Instytutu Geografii i Przestrzennego Zagospodarowania PAN. W opracowaniach ${ }^{8}$ następuje agregacja danych przede wszystkim do poziomu krajowego (ale również powiatowego i wojewódzkiego), uwzględniając różne grupy funkcjonalne gmin (m.in. miasta na prawach powiatu, gminy miejskie, gminy wiejskie, gminy miejsko-wiejskie). W analizach przedstawia się m.in. zmiany pokrycia mpzp, strukturę przeznaczenia terenów w obowiązujących planach miejscowych czy koszty związane $\mathrm{z}$ ich uchwaleniem. Analizie poddawane są także studia oraz decyzje o wz i ulicp.

Planowanie zagospodarowania przestrzennego jest jednym z podstawowych narzędzi realizacji rozwoju lokalnego przez samorządy gminne, uchwalanie mpzp przyczynia się bowiem do zwiększenia pośredniego oddziaływania gminy na działalność podmiotów gospodarczych (kreowanie warunków ich rozwoju), która służy zaspokojeniu potrzeb lokalnej społeczności

Jak wskazuje Andrzej Sztando ${ }^{10}$, monitoring jest niezbędny dla skutecznego i efektywnego oddziaływania samorządu gminnego na lokalny rozwój gospodarczy. W szerokim zakresie merytorycznym monitoringu wskazuje on m.in. strukturę zagospodarowania przestrzennego. Podkreśla także rolę monitoringu i modyfikacji mpzp jako narzędzi lokalnej polityki gospodarczej już na etapie implementacji. Monitoring jest ważny, gdyż błędy w planowaniu przestrzennym mogą stać się hamulcem rozwoju lokalnego ${ }^{11}$. Potrzebę monitoringu oraz oczekiwania samorządów dotyczące zintegrowanego zbierania i analizowania danych zwłaszcza w kontekście promowania równoważnych, najlepszych praktyk w zakresie pla-

\footnotetext{
${ }^{7}$ Rozporządzenie Rady Ministrów z 9 sierpnia 2013 r. w sprawie programu badań statystycznych statystyki publicznej na rok 2014 (DzU z 2013 r., poz. 1159).

${ }^{8}$ Np. P. Śleszyński, M. Górczyńska, A. Deręgowska, B. Zielińska, Analiza stanu i uwarunkowań prac planistycznych $w$ gminach na koniec 2011 roku, PAN IGiPZ, Warszawa, 2012.

${ }^{9}$ A. Kożuch, Rola samorzadu terytorialnego we wspieraniu rozwoju lokalnego, w: Instrumenty zarządzania rozwojem w przedsiębiorczych gminach, red. A. Kożuch, A. Noworól, Wydawnictwo Uniwersytetu Jagiellońskiego, Kraków 2011, s. 9-26.

10 A. Sztando, Gminny monitoring lokalnego rozwoju gospodarczego, w: Wspótczesne problemy polityki ekonomicznej, red. S. Korenik, Z. Przybyła, Wydawnictwo Akademii Ekonomicznej we Wrocławiu, Wrocław 2008, s. 269-280.

${ }^{11}$ A. Sztando, Progospodarcza polityka przestrzenna gmin, w: Gospodarka lokalna w teorii i praktyce, PN AE we Wrocławiu nr 979, Wrocław 2005, s. 193-202.
} 
nowania przestrzennego na przykładzie Nowej Zelandii przedstawili Bob Frame i Robert Vale ${ }^{12}$.

W przytoczonych wcześniej definicjach rozwoju lokalnego każdorazowo przywołany został ład przestrzenny. Jednym z gwarantów jego zachowania powinien być mpzp. W autorskiej propozycji wskaźników zagospodarowania i ładu przestrzennego wśród wskaźników prawno-planistycznych Przemysław Śleszyński ${ }^{13}$ zaproponował pokrycie planistyczne (udział terenów objętych obowiązującym mpzp) i rozdrobnienie planów miejscowych.

W poniższym opracowaniu poza pokryciem planistycznym analizie poddano również wskaźniki zagospodarowania terenu stosowane w mpzp.

\section{Metodyka}

Celem opracowania była ocena jakości uchwalanych planów miejscowych oraz jej zmian w latach 1995-2013 traktowana jako element monitoringu rozwoju lokalnego.

Materiał źródłowy do analiz stanowią wszystkie obowiązujące mpzp z wybranego obrębu geodezyjnego $\mathrm{w}$ gminie wiejskiej sąsiadującej z dużym miastem i podlegającej w związku z tym procesowi suburbanizacji. W artykule oceniono liczbę uchwalanych mpzp, ich powierzchnię, strukturę przeznaczenia terenu oraz stosowane wskaźniki zagospodarowania terenu:

- intensywność zabudowy,

- minimalny udział powierzchni biologicznie czynnej,

- maksymalna liczba budynków na działce,

- minimalna powierzchnia nowo wydzielonych działek,

- wysokość zabudowy wyrażona w metrach i/lub kondygnacjach.

Z uwagi na zróżnicowanie zastosowanych w mpzp na przestrzeni lat 1995$2013^{14}$ oznaczeń dla potrzeb analizy zostały one ujednolicone według rozporządzenia Ministra Infrastruktury w sprawie wymaganego zakresu projektu miejsco-

${ }^{12}$ B. Frame, R. Vale, Increasing Uptake of Low Impact Urban Design and Development: The Role of Sustainability Assessment „System, Local Environment” 2006, vol. 11, no. 3, s. 287-306.

${ }_{13}$ P. Śleszyński, Wskaźniki zagospodarowania i ładu przestrzennego. Propozycja autorska, w: Propozycje wskaźników do oceny i monitorowania zagospodarowania przestrzennego w gminach ze szczególnym uwzględnieniem zagadnienia ładu przestrzennego. Raport prac wykonanych $w$ etapie I i II, PAN IGiPZ, Warszawa 2012, s. 122-156.

${ }^{14}$ Zgodnie z ustawą z 27 marca 2003 r. o planowaniu i zagospodarowaniu przestrzennym plany uchwalone przed 1 stycznia 1995 r. traciły moc 31 grudnia 2003 r. 
wego planu zagospodarowania przestrzennego ${ }^{15}$, zgodnie z metodyką zaproponowaną przez Karola Mrozika i Annę Wiśniewską ${ }^{16}$. Analizy planów miejscowych dokonano z zastosowaniem oprogramowania firmy ESRI ArcGIS wersja 10.0. na podstawie bazy danych przestrzennych zawierającej poszczególne wskaźniki poddawane analizie.

Badania przeprowadzono na przykładzie obrębu geodezyjnego Skórzewo, w gminie wiejskiej Dopiewo w powiecie ziemskim poznańskim, położonego w bezpośrednim sąsiedztwie Poznania. Wieś ta podlega procesowi intensywnej suburbanizacji, co obrazuje np. wskaźnik dynamiki wzrostu ludności w latach 1995-2013, który w odniesieniu do 1995 r. wyniósł 422.

Skórzewo jest wsią pełniącą funkcję tzw. sypialni Poznania. Z tego względu większość powierzchni obejmowanych nowymi planami miejscowymi dotyczy przeznaczenia podstawowego pod zabudowę mieszkaniową jednorodzinną. Ta kategoria została wybrana do analizy stosowanych w poszczególnych latach wskaźników zagospodarowania terenu i kształtowania zabudowy kubaturowej.

Uzyskane wyniki odniesiono do danych statystycznych pochodzących z badania na temat „Planowania przestrzennego w gminach” udostępnionych na stronie Ministerstwa Infrastruktury i Rozwoju oraz GUS (stan na 31 grudnia 2013 r.).

\section{Wyniki badań}

Według stanu na 31 stycznia 2013 r. na obszarze obrębu geodezyjnego Skórzewo obowiązywało 39 planów miejscowych, które pokrywały 24\% analizowanego obszaru. Dla porównania w całej gminie Dopiewo obowiązywały 134 mpzp pokrywające zaledwie $10 \%$ obszaru gminy. Największy udział w strukturze pokrycia planistycznego, które według Śleszyńskiego ${ }^{17}$ można interpretować jako wskaźnik ładu przestrzennego $\mathrm{w}$ gminie $\mathrm{w}$ aspekcie prawnym, mają plany miejscowe z $2001 \mathrm{r}$. 29\%, 2008 r. - 14\%, 2003 r. - 11\% i 1997 r. - 11\%. Znaczna część terenów obecnie zainwestowanych w części południowo-wschodniej obrębu geodezyjnego Skórze-

${ }^{15}$ DzU z 2003 r., nr 164, poz. 1587.

${ }^{16}$ K. Mrozik, A. Wiśniewska, Miejscowe plany zagospodarowania przestrzennego jako instrument zarzadzania procesem suburbanizacji na terenach wiejskich na przykladzie obrębu geodezyjego Skórzewo, „Annual Set The Environment Protection” 2013, nr 15, s. 2128-2133.

17 P. Śleszyński, Wskaźniki zagospodarowania... 
wo pokryta była planami miejscowymi, które zgodnie z ustawą z 27 marca $2003 \mathrm{r}$. o planowaniu i zagospodarowaniu przestrzennym straciły moc 31 grudnia 2003 r. $^{18}$

W porównaniu do pozostałych gmin wiejskich powiatu poznańskiego (według stanu na 31 grudnia 2013 r. - tabela 1) sytuację w gminie Dopiewo można określić jako złą. Pokrycie na poziomie 10\% jest najniższe wśród rozpatrywanych gmin, w tym ponad czterokrotnie w stosunku do pozostałych gmin wiejskich powiatu poznańskiego i prawie dwukrotnie w porównaniu do wszystkich gmin wiejskich województwa wielkopolskiego. Nieco lepiej na tym tle wypada sam obręb geodezyjny Skórzewo, jednak biorąc pod uwagę intensywność zachodzących tam procesów inwestycyjnych pokrycie planistyczne na poziomie poniżej wartości dla ogółu gmin wiejskich powiatu poznańskiego, a tym bardziej ogółu gmin wiejskich w Polsce należy uznać za niewystarczające.

Tabela 1. Plany miejscowe w gminach wiejskich powiatu poznańskiego na tle gmin wiejskich Polski i województwa wielkopolskiego - stan na 31 grudnia $2013 \mathrm{r}$.

\begin{tabular}{|l|c|c|c|c|c|c|}
\hline \multirow{2}{*}{$\begin{array}{l}\text { Nazwa jednostki } \\
\text { administracyjnej }\end{array}$} & $\begin{array}{c}\text { Powierzch- } \\
\text { nia }\end{array}$ & \multirow{2}{*}{$\begin{array}{c}\text { Liczba } \\
\text { ludności }\end{array}$} & \multirow{2}{*}{$\begin{array}{c}\text { Liczba } \\
\text { mpzp }\end{array}$} & $\begin{array}{c}\text { Powierzch- } \\
\text { nia mpzp }\end{array}$ & $\begin{array}{c}\text { Pokrycie } \\
\text { gminy } \\
\text { mpzp }\end{array}$ & $\begin{array}{c}\text { Średnia po- } \\
\text { wierzchnia } \\
\text { mpzp }\end{array}$ \\
\cline { 5 - 7 } & ha & & & ha & $\%$ & ha \\
\hline Czerwonak & 8248 & 26285 & 44 & 1560 & 18,9 & 35,5 \\
\hline Dopiewo & 10802 & 19391 & 134 & 1134 & 10,5 & 8,46 \\
\hline Kleszczewo & 7446 & 6384 & 13 & 7446 & 100,0 & 572,8 \\
\hline Komorniki & 6641 & 20890 & 94 & 2683 & 40,4 & 28,5 \\
\hline Rokietnica & 7930 & 13294 & 88 & 1073 & 13,5 & 12,2 \\
\hline Suchy Las & 11601 & 15253 & 149 & 8721 & 75,2 & 58,5 \\
\hline Tarnowo Podgórne & 10175 & 22301 & 182 & 5257 & 51,7 & 28,9 \\
\hline $\begin{array}{l}\text { powiat poznański-gminy } \\
\text { wiejskie }\end{array}$ & 62843 & 123798 & 704 & 27874 & 44,4 & 39,6 \\
\hline $\begin{array}{l}\text { województwo wielkopol- } \\
\text { skie - gminy wiejskie }\end{array}$ & 1423194 & 881506 & 2803 & 254867 & 17,9 & 90,9 \\
\hline Polska - gminy wiejskie & 19735216 & 10931472 & 20433 & 5775552 & 29,3 & 282,7 \\
\hline Skórzewo & 710 & 4998 & 39 & 173 & 24,4 & 4,4 \\
\hline
\end{tabular}

Źródło: opracowanie własne na podstawie danych Urzędu Gminy Dopiewo, GUS i Ministerstwa Infrastruktury i Rozwoju.

18 Artykuł 87 ustawy z 27 marca 2003 r. o planowaniu i zagospodarowaniu przestrzennym (DzU z 2015 r., poz. 199 ze zm.). 
Także średnia powierzchnia uchwalanego planu miejscowego w gminie Dopiewo jest najmniejsza $(8,5$ ha) i jest dużo niższa niż w przypadku zagregowanych danych dotyczących ogółu gmin wiejskich w powiecie poznańskim, województwie wielkopolskim i w Polsce (tabela 1).

Warto podkreślić, że w przypadku gminy Kleszczewo wynik jest mylący, gdyż dla tej gminy uchwalono początkowo mpzp obejmujący cały jej obszar. Kolejne plany dotyczyły już tylko zmian planu miejscowego z 2005 r. Z kolei w Suchym Lesie pokrycie planistyczne obejmuje teren wojskowy Biedrusko o łącznej powierzchni 6318 ha stanowiący teren zamknięty.

Źle pod względem średniej powierzchni obowiązującego mpzp wypada zwłaszcza obręb geodezyjny Skórzewo. Od 1995 r. średniorocznie uchwalano 2 mpzp, a średnia powierzchnia pokrywana nowymi planami miejscowymi wynosiła rocznie 10 ha. Miejscowy plan o najmniejszej powierzchni $(0,03$ ha) powstał w $2003 \mathrm{r}$. Największy z kolei w 2001 r. objął powierzchnię 31,7 ha, przy czym powierzchnię łączną powyżej 20 ha miał poza wspomnianym jeszcze tylko plan z 2008 r. Z kolei mpzp o powierzchni powyżej 10 ha było łącznie zaledwie 5. Zdecydowanie dominowały natomiast plany najmniejsze o powierzchni do 1 ha (16 mpzp) opracowywane w skrajnych przypadkach dla jednej działki. Liczby te pokazują, iż zaledwie w kilku przypadkach możemy mówić o tworzeniu ładu przestrzennego dla jakiegoś większego zwartego funkcjonalnie obszaru. Przeważają plany będące wynikiem dostosowywania się do życzeń indywidualnego inwestora.

W obowiązujących w obrębie geodezyjnym Skórzewo mpzp dominuje jako przeznaczenie podstawowe zabudowa mieszkaniowa jednorodzinna (70\%), choć w licznych przypadkach dopuszczalna jest jako funkcja uzupełniająca także działalność gospodarcza - przede wszystkim nieuciążliwe usługi.

Drugą pod względem powierzchni kategorią przeznaczenia są tereny dróg publicznych (14\%). Znaczący jest także udział usług (12\%). Ne tereny zieleni urządzonej i wód powierzchniowych wolno stojących przypada około $2 \%$ powierzchni objętej planami. Tereny te związane są przede wszystkim z ciekami Skórzynką oraz Dopływem z Dąbrowy. Nowo uchwalane plany dotyczyły głównie terenów wcześniej użytkowanych rolniczo.

Analizując dane dotyczące przeznaczenia terenów, pochodzące ze sprawozdań PP- $1^{19}$, w gminie Dopiewo zwraca uwagę podobny udział terenów zabudowy miesz-

\footnotetext{
${ }^{19}$ Obecnie formularz PZP-1.
} 
kaniowej (65\%) i nieco większy terenów zabudowy usługowej (19\%), nie zostały jednak w ogóle wykazane tereny komunikacji oraz zieleni i wód, co wskazuje na dużą utratę istotnych danych. W sprawozdaniu wykazane natomiast zostały tereny infrastruktury technicznej (2\%) i użytkowane rolniczo (14\%). W gminie Kleszczewo aż 79\% powierzchni przypada na użytkowanie rolnicze, gdyż gmina posiada rolniczy charakter, a mpzp, jak wspomniano wcześniej, obejmuje całą gminę. Z kolei w gminie Suchy Las aż 86\% wskazywanego przeznaczenia to tereny zieleni i wód, czyli przede wszystkim teren wojskowy Biedrusko. Na podobnym poziomie wykazane zostało przeznaczenie pod zabudowę mieszkaniową na terenie gmin Rokietnica (52\%) i Tarnowo Podgórne (47\%), przy czym w Tarnowie Podgórnym aż 15\% stanowi zabudowa wielorodzinna (w Rokietnicy -3\%). Tereny komunikacji obejmują około 7\% powierzchni obowiązujących mpzp.

Rysunek 1. Liczba planów miejscowych uwzględniających analizowane wskaźniki urbanistyczne

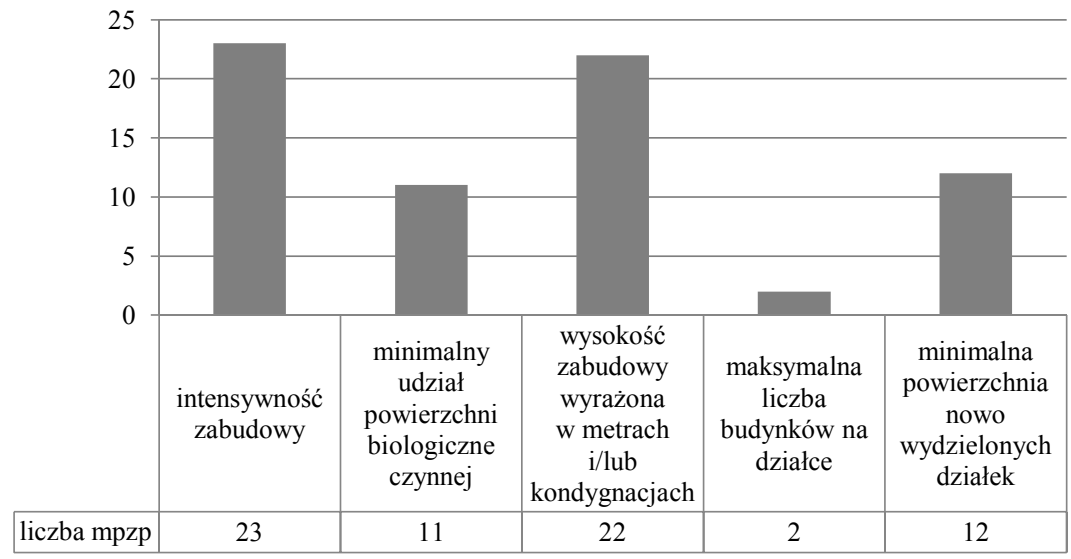

Źródło: opracowanie własne.

Szczegółową analizę jakościową obowiązujących mpzp przeprowadzono dla planów miejscowych dotyczących terenów zabudowy mieszkaniowej jednorodzinnej - ogółem 26. W artykule przyjęto założenie, że większa liczba zastosowanych wskaźników świadczy o wyższej jakości uchwalanych dokumentów i przyczynia się w większym stopniu do kształtowania ładu przestrzennego. Wśród rozpatrywanych 
5 wskaźników najczęściej wskazywane były: intensywność zabudowy (maksymalna powierzchnia zabudowy) (23 x) i wysokość zabudowy (22 x) (rysunek 1). Zaledwie dwa plany wskazywały maksymalną liczbę budynków na działce. Przeciętny plan zawierał 3 spośród analizowanych 5 wskaźników, przy czym tylko jeden (uchwała XXXIV/290/01) zawierał wszystkie 5. Także jeden (uchwała XXX_242_2000) nie posiadał odniesienia do żadnego konkretnego wskaźnika (rysunek 2). Warto odnotować, że ostatnie z analizowanych 5 planów (z lat 2008-2013) zawierały 4 z rozpatrywanych 5 wskazań, co jednoznacznie świadczy o podnoszeniu standardów opracowywanych dokumentów, ale również o ich ujednoliceniu.

Rysunek 2. Liczba planów miejscowych w zależności od liczby zastosowanych wskaźników

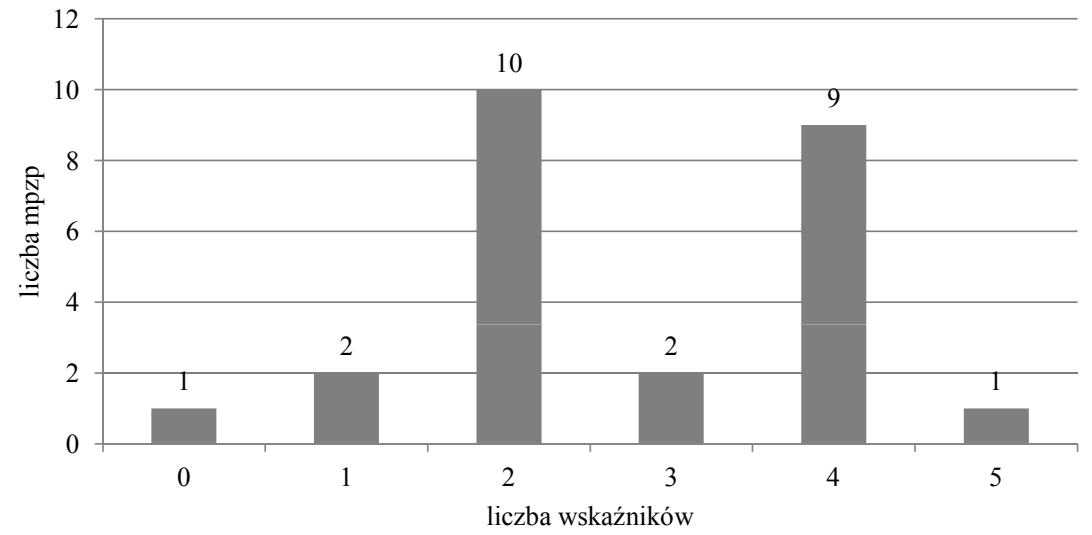

Źródło: opracowanie własne.

\section{Podsumowanie}

W projekcie kodeksu urbanistyczno-budowlanego wskazano, że planowe gospodarowanie przestrzenią tworzy podstawy dla działalności inwestycyjnej w gminie $^{20}$. Przeprowadzone w opracowaniu analizy wykazały wzrost szczegółowości zapisów stosowanych w planach miejscowych w latach 1995-2013 mierzony liczbą

\footnotetext{
${ }^{20}$ I. Foryś, M. Nowak, Zarzadzanie przestrzenia w gospodarowaniu nieruchomościami, Poltext, Warszawa 2014, s. 152.
} 
wprowadzonych wskaźników zagospodarowania terenu i utrzymywanie wysokiego poziomu stosowania tych wskaźników, począwszy od 2008 r. Świadczy to o większym zainteresowaniu lokalnych władz tworzeniem czytelnych dla inwestora zasad zagospodarowania, a tym samym warunków dla rozwoju lokalnego, który ma zapewnić ład przestrzenny.

Wzrastające pokrycie powierzchni gminy planami miejscowymi, tym bardziej charakteryzującymi się większą dbałością o zachowanie wskaźników zagospodarowania terenu, stwarza warunki do zrównoważonego rozwoju lokalnego z poszanowaniem zasady ładu przestrzennego. Należy jednak podkreślić, że prosta analiza pokrycia planistycznego $\mathrm{w}$ gminach wiejskich powiatu poznańskiego wykazała, że surowe dane statystyczne bez znajomości lokalnych uwarunkowań mogą prowadzić do znacznych błędów interpretacyjnych. Nie można zatem bezkrytycznie łączyć pokrycia planistycznego z korzystnymi warunkami dla rozwoju lokalnego.

Potrzebę szczegółowego monitoringu planów miejscowych potwierdza fakt znacznego rozdrobnienia uchwalanych mpzp. $Z$ jednej strony można to interpretować jako otwartość gminy na propozycje inwestora, z drugiej jednak takie działania mogą prowadzić do zachwiania ładu przestrzennego, a tym samym utraty atrakcyjności inwestycyjnej znacznie większych obszarów i zasadniczo należy je traktować jako niezgodne z konstytucyjną zasadą zrównoważonego rozwoju.

\section{Literatura}

Brol R., Rozwój lokalny - nowa logika rozwoju gospodarczego, w: Gospodarka lokalna w teorii i praktyce, PN AE we Wrocławiu nr 785, Wrocław 1998.

Foryś I., Nowak M., Zarzadzanie przestrzenia w gospodarowaniu nieruchomościami, Poltext, Warszawa 2014.

Frame B., Vale R., Increasing Uptake of Low Impact Urban Design and Development: The Role of Sustainability Assessment System, „Local Environment” 2006, vol. 11, no. 3.

Kożuch A., Rola samorzadu terytorialnego we wspieraniu rozwoju lokalnego, w: Instrumenty zarządzania rozwojem $w$ przedsiębiorczych gminach, red. A. Kożuch, A. Noworól, Wydawnictwo Uniwersytetu Jagiellońskiego, Kraków 2011.

Mrozik K., Wiśniewska A., Miejscowe plany zagospodarowania przestrzennego jako instrument zarzadzania procesem suburbanizacji na terenach wiejskich na przykladzie obrębu geodezyjego Skórzewo, „Annual Set The Environment Protection” 2013, nr 15.

Parysek J.J., Podstawy gospodarki lokalnej, Wydawnictwo Uniwersytetu im. Adama Mickiewicza, Poznań 2001. 
Sztando A., Gminny monitoring lokalnego rozwoju gospodarczego, w: Wspótczesne problemy polityki ekonomicznej, red. S. Korenik, Z. Przybyła, Wydawnictwo Akademii Ekonomicznej we Wrocławiu, Wrocław 2008.

Sztando A., Progospodarcza polityka przestrzenna gmin, w: Gospodarka lokalna w teorii i praktyce, PN AE we Wrocławiu nr 979, Wrocław 2005.

Śleszyński P., Wskaźniki zagospodarowania i ładu przestrzennego. Propozycja autorska, w: Propozycje wskaźników do oceny i monitorowania zagospodarowania przestrzennego w gminach ze szczególnym uwzględnieniem zagadnienia ładu przestrzennego. Raport prac wykonanych w etapie I i II, PAN IGiPZ, Warszawa 2012.

Rozporządzenie Ministra Infrastruktury z 26 sierpnia 2003 r. w sprawie wymaganego zakresu projektu miejscowego planu zagospodarowania przestrzennego (DzU z 2003 r., nr 164, poz. 1587).

Rozporządzenie Rady Ministrów z 12 kwietnia 2012 r. w sprawie Krajowych Ram Interoperacyjności, minimalnych wymagań dla rejestrów publicznych i wymiany informacji w postaci elektronicznej oraz minimalnych wymagań dla systemów teleinformatycznych (DzU z 2012 r., poz. 526).

Rozporządzenie Rady Ministrów z 9 sierpnia 2013 r. w sprawie programu badań statystycznych statystyki publicznej na rok 2014 (DzU z 2013 r., poz. 1159).

Śleszyński P., Górczyńska M., Deręgowska A., Zielińska B., Analiza stanu i uwarunkowań prac planistycznych w gminach na koniec 2011 roku, PAN IGiPZ, Warszawa 2012.

Ustawa z 8 marca 1990 r. o samorządzie gminnym (DzU z 2013 r., poz. 594 ze zm.).

Ustawa z 27 marca 2003 r. o planowaniu i zagospodarowaniu przestrzennym (DzU z 2015 r., poz. 199 ze zm.).

Ustawa z 4 marca 2010 r. o infrastrukturze informacji przestrzennej (DzU z 2010 r., nr 76, poz. 489 ze zm.).

\title{
LOCAL SPATIAL DEVELOPMENT PLANS AS AN ELEMENT OF THE LOCAL DEVELOPMENT MONITORING
}

\begin{abstract}
Land development planning is one of the basic tools for the implementation of local development by the local governments. In turn the monitoring is essential for effective and efficient impact of local government on local development. The study analyzed the coverage of local spatial development plans in rural communes of Poznan district. A detailed qualitative analysis of binding local plans (taking into account indicators used in local plans) was
\end{abstract}


carried out for the local plans for the single-family housing areas (total 26) within the geodesic precinct Skorzewo, Dopiewo commune, Poznan district.

Keywords: local spatial development plan, local development, suburbanization, monitoring, rural commune, Poznan district

JEL Codes: O18, O20, R58, Q01

Translated by Karol Mrozik

Praca zrealizowana w ramach projektu badawczego NCN nr 2013/09/D/HS4/01858. 